\title{
Regulation of vitamin D receptor expression via estrogen-induced activation of the ERK $1 / 2$ signaling pathway in colon and breast cancer cells
}

\author{
Liat Abovich Gilad, Tali Bresler, Julia Gnainsky, Patricia Smirnoff \\ and Betty Schwartz
}

Institute of Biochemistry, Food Science and Nutrition, Faculty of Agricultural, Food and Environmental Quality Sciences, The Hebrew University of Jerusalem, P.O. Box 12, Rehovot 76100, Israel

(Requests for offprints should be addressed to B Schwartz; Email: bschwart@agri.huji.ac.il)

\begin{abstract}
We previously demonstrated that $17 \beta$-estradiol (E2) regulates the transcription and expression of the vitamin D receptor (VDR) in rat colonocytes and duodenocytes in vivo. The aim of the present study was to assess whether the extracellular signal-regulated kinase (ERK) induced by $\mathrm{E} 2$ is involved in regulating VDR expression. We compared E2-associated signaling activity in HT29 colon cancer cells, a non-classical E2-target, with that in MCF-7 breast cancer cells, the natural targets of the hormone. E2 did not affect proliferation of HT29 cells, but enhanced proliferation of MCF-7 cells. Vitamin D inhibited proliferation of both cell lines and the combined treatment induced potentiation of vitamin D activity. E2 upregulated VDR transcription and protein expression concomitantly with ERK 1/2 phosphorylation in both cell lines. PD98059, a specific mitogen-activated protein kinase (MAPK) inhibitor, prevented E2-mediated activation of ERK 1/2, with concomitant inhibition of VDR expression. ICI182780 inhibited VDR expression in HT29 and MCF-7 cell lines. A conjugate of E2 and bovine serum albumin upregulated phosphorylation of ERK $1 / 2$ and concomitantly enhanced VDR expression in a similar fashion as the nonconjugated hormone. Expression of ER $\alpha$ and ER $\beta$ was detected in MCF-7 and HT29 cell lines
\end{abstract}

respectively, which localized to the nuclei, cytosol and caveolar membrane rather than non-caveolar membrane. Disruption of lipid rafts/caveolae by depleting cellular cholesterol with the cholesterol-binding reagent $\beta$ methylcyclodextrin blocked ERK 1/2 phosphorylation concomitantly with VDR upregulation. The tyrosine phosphorylation inhibitor suramin and src kinase inhibitor PP2 inhibited both ERK 1/2 phosphorylation and VDR expression. E2 induced phosphorylation of Raf and Jun in a time-dependent manner. The Ras/Raf dependent inhibitor of transactivation sulindac sulfide also blocked E2 effects. The specific c-Jun phosphorylation inhibitor SP600125 dose dependently inhibited c-Jun phosphorylation and VDR expression. The MAPK/ERK kinase inhibitor PD 98059 downregulated both c-Jun phosphorylation and VDR expression indicating that upstream and downstream events in the signaling cascade are all related to the control of VDR expression. Taken together, our data suggest that E2 binds to receptors compartmentalized to membranal caveolar domains in HT29 and MCF-7 cells, inducing ERK 1/2 activation and transcriptional activity, which finally results in upregulation of expression of the VDR gene.

Journal of Endocrinology (2005) 185, 577-592

\section{Introduction}

Estrogen receptor (ER) is a member of a superfamily of nuclear transcription factors. The cellular actions of estrogen are thought to be mediated through transcriptional regulation of target genes (Halachmi et al. 1994, Glass et al. 1997). This process occurs mainly when $17 \beta$-estradiol (E2) binds to nuclear ER. The resultant complex then binds directly to response elements present on various genes (Nilsson et al. 2001) or modifies transcription through protein-protein interactions prior to DNA binding (Pfahl 1993). When ER binds to E2, it undergoes a conforma- tional change that results in dimerization, binding to specific DNA elements, and transcriptional regulation of target genes (Nahmias \& Strosberg 1995, Csikos et al. 1998). It is becoming increasingly clear, however that multiple ligands for the steroid receptor superfamily can modulate cell function through nongenomic actions mediated through plasma-membrane proteins (Blackmore et al. 1991, Nemere et al. 1994, Wehling 1995). For example there is evidence that E2 can trigger a variety of signal-transduction events within seconds to a few minutes. These events include stimulation of adenylate cyclase (Aronica et al. 1994), activation of phospholipase C 
(Le Mellay et al. 1997), and triggering of an intracellular calcium spike (Tesarik \& Menoza 1995). Additionally, a putative cell-membrane ER, the existence of which was first reported more than 20 years ago (Pietras \& Szego 1977, 1980), appears capable of activating signal-transduction pathways according to more recent investigations (Berthois et al. 1986, Pappas et al. 1995).

There is also evidence that E2 may be directly involved in determining intestinal calcium absorption. Because intestinal calcium absorption decline with age in humans (Avioli et al. 1965, Bullamore et al. 1970) and rats (Russell et al. 1986), a commonly held hypothesis suggests that this decreased absorption results from a sequence of events initiated by low estrogen levels, which result in bone resorption. According to this hypothesis, the released calcium increases the calcium concentration in extracellular spaces, thus suppressing parathyroid hormone secretion, a decrease in $1,25(\mathrm{OH})_{2} \mathrm{D}_{3}$ production and plasma concentration follows, finally resulting in decreased intestinal calcium absorption (Gallagher et al. 1979).

E2 receptors (Francavilla et al. 1987, Meggouh et al. 1991, Hendrickse et al. 1993), as well as the ER-associated proteins pS2 antigen (Theisinger et al. 1993, Luqmani et al. 1992, Welter et al. 1994) and ER-D5 (Takeda et al. 1992), are consistently found in the mucosa along the alimentary tract, suggesting a specific physiologic role for E2 in the intestine. In this regard, available data indicate that decreased basal levels of $1,25(\mathrm{OH})_{2} \mathrm{D}_{3}$ cannot solely account for the decrease in calcium absorption (Francis et al. 1984), suggesting that the intestines of estrogen-depleted elderly or ovariectomized women are resistant to $1,25(\mathrm{OH})_{2} \mathrm{D}_{3}$ (Gennari et al. 1990). In addition, E2 administration has been shown to effectively restore the normal responsiveness of the intestine to $1,25(\mathrm{OH})_{2} \mathrm{D}_{3}$ in ovariectomized pre- (Gennari et al. 1990) and postmenopausal (Civitelli et al. 1988, Heaney et al. 1978) women.

Previous studies have also indicated an age-related decrease in the number of VDR (Horst et al. 1990, Takamoto et al. 1990). The number of VDR is a primary determinant of the biological response to $1,25(\mathrm{OH})_{2} \mathrm{D}_{3}$, as previously shown in osteoblastic cell lines (Dokoh et al. 1984, Liel et al. 1992) and in human populations in association with VDR-gene polymorphism (Gross et al. 1996, Arai et al. 1997, Harris et al. 1997). E2 has been shown to increase the number of VDR in the osteoblastlike cell line $\operatorname{ROS} 17 / 2 \cdot 8$, an increase associated with enhanced responsiveness of the cells to $1,25(\mathrm{OH})_{2} \mathrm{D}_{3}$ (Liel et al. 1992). Increased VDR expression following E2 treatment has also been noted in other tissues and cell types, such as the uterus (Walters 1981, Levy et al. 1984), liver (Duncan et al. 1991), and human breast cancer cells (Escaleira et al. 1993).

Rapid activation of mitogen-activated protein kinase (MAPK) by E2 in ROS $17 / 2 \cdot 8$ cells has provided the first evidence of MAPK activation by E2 through phosphorylation, indicating the involvement of putative plasma- membrane receptors (Migliaccio et al. 1996, Endoh et al. 1997). Rapid effects exerted by E2 on growth-factorrelated signaling pathways have also been demonstrated in neuronal cells, suggesting a potential mechanism by which E2 might affect the expression of genes with promoters that do not contain strictly estrogen-responsive elements but are responsive to factors acting through other response elements, such as activation protein-1 (AP-1) and serum response elements (Watters et al. 1997).

Detailed mechanisms whereby MAPK activation mediates E2 gene regulation remain speculative. The present study was designed to investigate the nature of the interactions between E2, the MAPK signaling pathway, and VDR in cells representative of various organs: namely HT29 cells, considered to be classic non-E2 targets, and MCF-7 cells, considered to be typical E2 targets. Herein we present molecular evidence that E2 regulates VDR gene expression via binding to caveolar membranal ER, and activates downstream signaling involving the MAPK pathway.

\section{Materials and Methods}

\section{Materials}

Suramin, sulindac sulfide, $\beta$-methylcyclodextrin and an E2-6-(O-carboxylmethyloxime-BSA)-conjugate were purchased from Sigma Chemical Co. (St Louis, MO, USA). PP2 was purchased from Calbiochem (La Jolla, CA, USA). Tissue culture media and antibiotic antimycotic solution supplements were obtained from Biological Industries Beit Haemek LTD, Israel. The PhosphoPlus p42/44 MAPK antibody kit was from New England Biolabs, Inc. (Beverly, MA, USA). Monoclonal human anti-VDR antibody and rabbit anti-Raf-1 antibody were from Santa Cruz Biotechnology, Inc. (Santa Cruz, CA, USA). Rabbit anti-ER $\beta$ polyclonal antibody was from Chemicon (Temecula, CA, USA), and ER $\alpha$ monoclonal antibody was from Cell Signaling Technology, Inc. (Beverly, MA, USA). Polyclonal antiserum to caveolin-1 was from Transduction Laboratories, Inc. (Lexington, KY, USA). Phospho-Raf, Phospho-c-Jun and c-Jun antibodies were purchased from Cell Signaling Technology, Inc. (Beverly, MA, USA). The enhanced chemiluminescence kit was from Amersham Biosciences (Buckinghamshire, UK). The protein determination kit, based on bicinchoninic acid, was obtained from Pierce (Rockford, IL, USA). PD98059, an inhibitor of MEK activation was purchased from Biomol Research Laboratories, Inc. (Plymouth Meeting, PA, USA). ICI182780 was purchased from Tocris (Bristol, UK). All other biochemicals were purchased from Sigma Chemical Co.

\section{Cell lines and culture conditions}

HT29, a human colon adenocarcinoma cell line, was cultured in DMEM supplemented with 10\% (w/v) FCS, 
$1 \%(\mathrm{w} / \mathrm{v})$ L-glutamine, and $0 \cdot 2 \%(\mathrm{w} / \mathrm{v})$ antibiotic antimycotic solution 1 and was maintained under a humidified atmosphere and $5 \%$ carbon dioxide at $37{ }^{\circ} \mathrm{C}$. MCF-7, a human breast cancer cell line, was cultured similarly, but the medium was also supplemented with $2 \%(\mathrm{w} / \mathrm{v})$ insulin solution. MCF-7 cells were grown to $80-90 \%$ confluence and the medium was replaced every other day.

\section{Treatment of cells}

Cells were harvested, washed twice by centrifugation in PBS and then cultured in $50 \mathrm{ml}$ flasks or into 6-well plates in DMEM with phenol red (PR) or DMEM without PR supplemented with 10\% charcoal-stripped FCS, 1\% L-glutamine and $0 \cdot 2 \%$ antibiotic solution. Cells were treated with different concentrations of E2 (from $10^{-11}$ to $10^{-7} \mathrm{M}$ ) dissolved in ethanol. Control cultures included ethanol at a final concentration of $0.0067 \%$ in the medium. For proliferation analyses, cells were exposed to a medium containing the designated treatment for 6 days, which was found to be the optimal time period in preliminary experiments (data not shown). Treatment and medium were replaced every other day. To study the involvement of the MAPK signal-transduction pathway, cells were treated with different concentrations of $\mathrm{E} 2$ in the presence or absence of $5 \times 10^{-5} \mathrm{M}$ PD98059 or IGF-I $(100 \mathrm{ng} / \mathrm{ml})$. To study the role of ER, cells were treated with $10^{-6} \mathrm{M}$ ICI182780. To study the role of membrane-bound tyrosine phosphorylation activity, cells were treated with suramin at concentrations between $0.05 \times 10^{-3} \mathrm{M}$ and $4 \times 10^{-3} \mathrm{M}$ and concomitantly incubated with E2 to determine ERK $1 / 2$ activation analyses or VDR expression. In companion studies cells were treated with different concentrations of PP2 (4-amino-5-(4-chlorophenyl)-7-(t-butyl)pyrazolo[3,4-d]pyrimidine) which was purchased from Calbiochem and dissolved in dimethyl sulfoxide (DMSO). Sulindac sulfide was also dissolved in DMSO and added to cells at a concentration of $100 \mu \mathrm{M}$. The potent inhibitor of c-Jun N-terminal kinase (SP600125) was obtained from Calbiochem and dissolved in DMSO. Drugs were freshly diluted in culture media for each experiment.

\section{Subcellular fractionations}

Subcellular fractions were prepared from HT29 or MCF-7 cells. Cells were washed three times with PBS, and then homogenized at $1000 \mathrm{~g}$ in $50 \mathrm{mM}$ Tris- $\mathrm{HCl}(\mathrm{pH} 7 \cdot 5)$ containing general-purpose protease inhibitor cocktail basically as recently described by Chaban et al (2004). Nuclear pellets were collected through low-speed centrifugation. The remaining supernatant was centrifuged at $49000 \mathrm{~g}$ for $15 \mathrm{~min}$ at $4{ }^{\circ} \mathrm{C}$. The supernatant, containing nonmembrane proteins, i.e. the cytosol, was collected. The pellet was washed with $300 \mu \mathrm{l}$ of $50 \mathrm{mM}$ Tris $\mathrm{pH} 7 \cdot 5$ containing protease inhibitors and centrifuged at $49000 \mathrm{~g}$ for $15 \mathrm{~min}$ at $4{ }^{\circ} \mathrm{C}$ to pellet the membranes. Different subcellular protein fractions were separated on SDS-PAGE gels, blotted and probed with antibodies against $\operatorname{ER} \alpha$ and ER $\beta$.

\section{Isolation of caveolae}

HT29 and MCF-7 cells were grown to confluence in $150 \mathrm{~mm}$ dishes and non-treated or treated with E2 (10-7 M). We prepared caveolin-enriched membrane fractions, without the use of detergent and the use of sodium carbonate buffer, following the detergent-free protocol developed by Song et al. (1995). After two washes with ice-cold PBS, HT29 and MCF-7 (two confluent $150 \mathrm{~mm}$ dishes) were scraped into $2 \mathrm{ml}$ of $500 \mathrm{mM}$ sodium carbonate, $\mathrm{pH} 11 \cdot 0$. Homogenization was carried out sequentially in the following order using a loose-fitting Dounce homogenizer (10 strokes), a Polytron tissue grinder (three 10 s bursts; Kinematica $\mathrm{GmbH}$, Brinkmann Instruments, Westbury, NY, USA), and a sonicator (three $20 \mathrm{~s}$ bursts; Branson Sonifier 250, Branson Ultrasonic Corp., Danbury, CT, USA). The homogenate was then adjusted to $45 \%$ sucrose by the addition of $2 \mathrm{ml}$ of $90 \%$ sucrose prepared in MES-buffered saline (MBS) $(25 \mathrm{mM}$ MES, pH $6 \cdot 5,0 \cdot 15 \mathrm{M} \mathrm{NaCl}$ ) and placed at the bottom of an ultracentrifuge tube. A 5-35\% discontinuous sucrose gradient was formed above $(4 \mathrm{ml}$ of $5 \%$ sucrose $/ 4 \mathrm{ml}$ of $35 \%$ sucrose; both in MBS containing $250 \mathrm{mM}$ sodium carbonate) and centrifuged at $200000 \mathrm{~g}$ for $16-20 \mathrm{~h}$ in an SW41 rotor (Beckman Instruments, Palo Alto, CA, USA). A light-scattering band confined to the 5-35\% sucrose interface was observed that contained caveolin but excluded most other cellular proteins.

Successful separation of caveolae from non-caveolae plasma membrane was confirmed by immunoblot analyses for the caveolae marker protein caveolin-1 (Chang et al 1994).

\section{Western blot analysis}

Cells were lysed, electrophoresed on 10\% sodium dodecyl sulfate polyacrylamide gels, transferred to nylon-transfer membranes (Amersham Biosciences, Buckinghamshire, $\mathrm{UK}$ ), blocked in $10^{-3} \mathrm{M}$ Tris-base and $0 \cdot 1 \mathrm{M}$ sodium chloride, containing 5\% dry nonfat milk, incubated with monoclonal human anti-VDR antibody, and subsequently incubated with a secondary antibody coupled to horseradish peroxidase. Proteins were visualized using an ECL kit (Amersham Biosciences, Buckinghamshire, UK). Signal intensities were analyzed by a BAS1000 Bio-Image Analyzer (Fuji, Tokyo, Japan) and the densities were quantified with the NIH computer program Image $1 \cdot 19$ (NIH, Bethesda, MD, USA).

To determine ERK 1/2 phosphorylation, HT29 and MCF-7 cells were plated in six-well plates in DMEM-PR and gradually deprived of FCS as follows: cells were 
exposed for 2 days to $0.5 \%$ charcoal-stripped FCSDMEM-PR, and then to media devoid of FCS for $24 \mathrm{~h}$ including different concentrations of $\mathrm{E} 2$ in the presence or absence of $5 \times 10^{-5} \mathrm{M}$ PD98059. Western blot was performed on cell lysates using a rabbit polyclonal phospho-p42/44 MAPK (Thr202/Tyr204) antibody.

Effect of the E2-BSA conjugate on ERK 1/2 phosphorylation

Before each experiment, stock solutions of BSA conjugates were submitted to charcoal dextran $(0.05 \mathrm{mg} / \mathrm{ml})$ and charcoal $(50 \mathrm{mg} / \mathrm{ml})$ for $30 \mathrm{~min}$, centrifuged at $3000 \boldsymbol{g}$ for $10 \mathrm{~min}$ and filtered through a $0 \cdot 22 \mathrm{~m}$ filter to obtain E2-BSA free of unbound E2. E2-BSA was dissolved in phenol-free growth medium at $0 \cdot 2 \mathrm{mg} / \mathrm{ml}$. The concentration of BSA conjugate was adjusted to the values of the free hormone.

\section{RT-PCR analyses}

RNA isolation was preformed using Tri Reagent solution (MRC, Cincinnati, OH, USA). RT-PCR assay was performed using the Promega kit assay (Madison, WI, USA). The specific selected VDR primers were $5^{\prime}-$ ATGCCATCTGCATCGTCTC-3' and $5^{\prime}$-GCACCG CACAGGCTGTCCTA- $3^{\prime}$. The PCR protocol was 5 min at $94{ }^{\circ} \mathrm{C}$, then 31 cycles $\left(1 \mathrm{~min}\right.$ at $94{ }^{\circ} \mathrm{C}, 1 \mathrm{~min}$ at $54{ }^{\circ} \mathrm{C}$ and $1 \mathrm{~min}$ at $72{ }^{\circ} \mathrm{C}$ ), and finally $10 \mathrm{~min}$ at $72{ }^{\circ} \mathrm{C}$.

\section{Statistical analyses}

Presented data represent means \pm S.E Differences between the control and treatments were evaluated by Student's $t$-test.

\section{Results}

Expression of ERa and ER $\beta$ in HT29 and MCF-7 cells

HT29 and MCF-7 cell lines were chosen for the present studies because HT29 cells are considered classic non-E2 targets, whereas MCF-7 cells are considered typical E2 targets. Western blot analyses were performed with specific anti-ER $\alpha$ and -ER $\beta$ antibodies. MCF-7 cells expressed both ER $\alpha$ and ER $\beta$, but in HT29 cells, we detected only ER $\beta$ (Fig. 1). Equal loading was verified by Ponceau red staining (not shown).

Effect of E2, vitamin D and combination of E2 and vitamin $D$ on cell growth

We analyzed whether E2 can directly affect the proliferation of HT29 and MCF-7 cells. E2 induced enhanced proliferation of MCF-7 cells at a concentration range

\section{HT29 MCF7 \\ $\therefore \operatorname{ER\alpha } 67 \mathrm{kDa}$ \\ $\operatorname{ER} \beta 54 \mathrm{kDa}$}

Figure 1 Expression of ER $\alpha$ and ER $\beta$ in HT29 and MCF-7 cells. Western blot of HT29 and MCF-7 cell lysates with specific ER antibodies.

of $10^{-7}-10^{-11} \mathrm{M}$ (Fig. 2B). In contrast, E2 at the same concentrations did not exert any significant effect on the HT29 proliferation rate after 3, 6 or 9 days at any of these hormone concentrations (Fig. 2A). This difference may be due to the differential repertoires of expression of $E R \alpha$ and ER $\beta$ in these cell lines (see Fig. 1). We next analyzed whether E2 and vitamin D (D), as single treatments or in combination, can affect HT29 and MCF-7 cell proliferation. The treatment lasted 6 days. Figs $3 \mathrm{~A}$ and $\mathrm{B}$ show that E2 at $10^{-8} \mathrm{M}$ did not inhibit proliferation in HT29 or MCF-7 cells, but, a significant anti-proliferative effect was
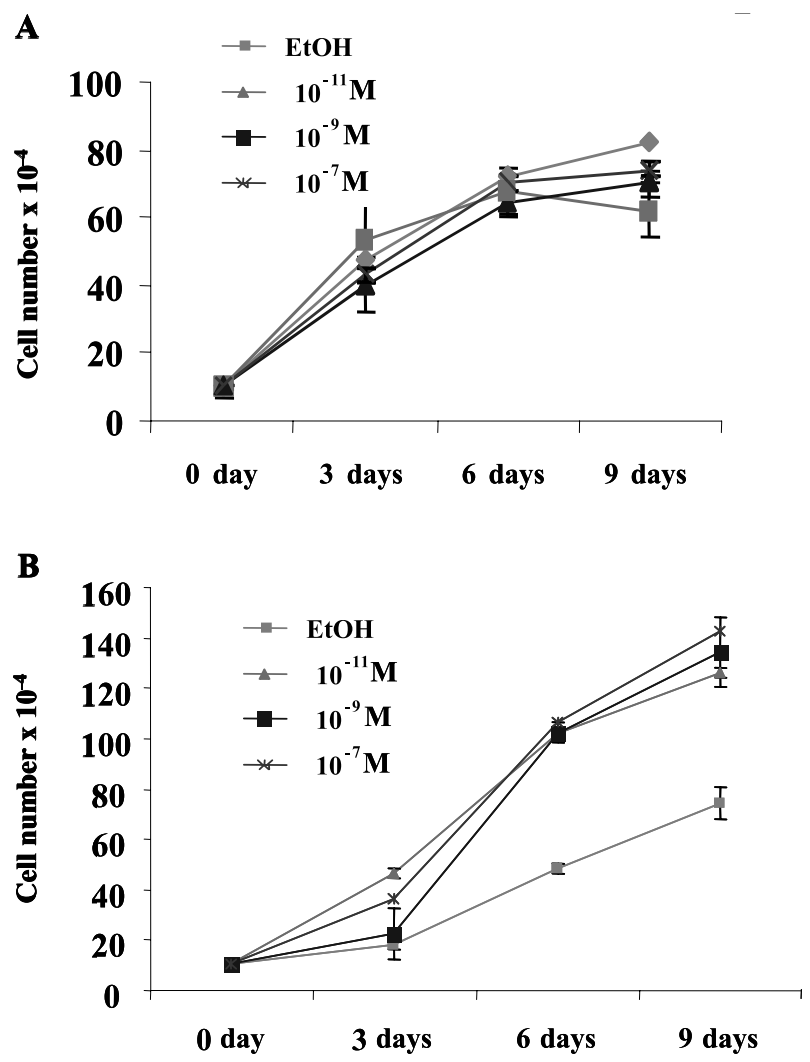

Figure 2 Effect of E2 on HT29 and MCF-7 cancer cell growth. HT29 (A) and MCF-7 (B) cells were treated with different E2 concentrations for 3, 6, or 9 days. Medium was replaced every other day. Control cells were treated with the E2 vehicle (ethanol) at the maximum concentration used in the experiment, $0.0067 \%$. $\mathrm{EtOH}$, ethanol. 


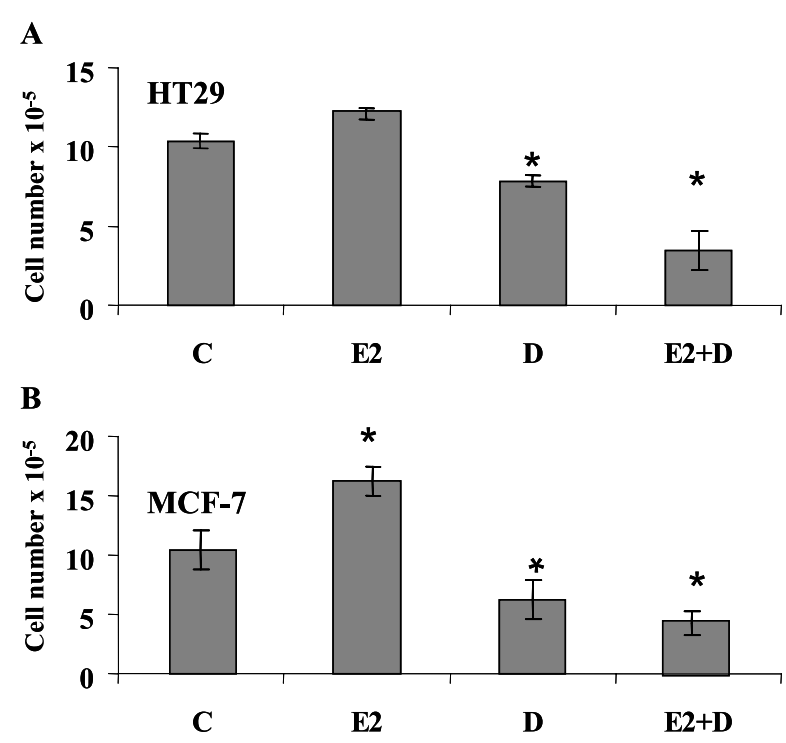

Figure 3 Effects of E2, D and combined E2+D treatment on HT29 and MCF-7 cancer cell growth. Cells were exposed for 6 days to individual or combined treatments of $10^{-8} \mathrm{M}$ estradiol (E2), $10^{-8} \mathrm{M}$ Vitamin D (D). Control cells (C) were treated with vehicle control (0.0067\% ethanol). ${ }^{*} P<0 \cdot 005$.

observed when both cell lines were exposed to $10^{-8} \mathrm{M} \mathrm{D}$ $(P<0 \cdot 005)$, effect that was significantly potentiated following combined $10^{-8} \mathrm{M} \mathrm{E} 2$ and $10^{-8} \mathrm{M} \mathrm{D}$ treatments $(P<0 \cdot 001)$.

Effect of E2 on VDR $m R N A$ and protein-expression levels in HT29 and MCF-7 cells

Previously we demonstrated that E2 regulates the transcription and expression of VDR in rat colonocytes and duodenocytes in vivo (Liel et al. 1999, Schwartz et al. 2000). Here, we analyzed the effect of E2 on VDR mRNA and protein expression in HT29 and MCF-7 cells. E2 upregulated VDR transcription in both cell lines; mRNA expression was enhanced in HT29 (Fig. 4A) and MCF-7 (Fig. 4B) following treatment with E2.

The effect of E2 on VDR protein expression was assessed by western blot analysis in both HT29 (Fig. 5A) and MCF-7 cells (Fig. 5B). Densitometric analyses showed that $\mathrm{E} 2$ at all concentrations tested $\left(10^{-11}-10^{-7} \mathrm{M}\right)$ significantly upregulated VDR expression in both cell lines. Both HT29 and MCF-7 cells were exposed to a medium containing the hormonal treatment for 6 days, which was found to be the optimal time period in preliminary experiments (data not shown). In HT29 cells, the increase in VDR expression was dependent on E2 dose, reaching highest significance $(P<0 \cdot 01)$ at $10^{-7} \mathrm{M}$ (Fig. 5A). In MCF-7 cells, up-regulation of VDR expression followed a similar pattern as in HT-29 cells, and reached highest significance at $10^{-9} \mathrm{M}$. The specific ER inhibitor ICI182780 blocked E2-mediated VDR upregulation in
A

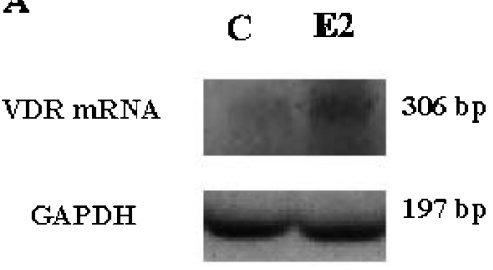

B

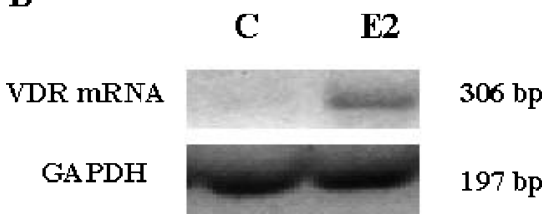

Figure 4 VDR mRNA expression. HT29 (A) and MCF-7 (B) cells were treated with $10^{-7} \mathrm{ME2}$, and RNA extracts were analyzed for VDR mRNA expression by RT-PCR, as compared to GAPDH expression.

both cell lines, suggesting that E2 mediates VDR expression via a process involving ER's (Fig. 5C). In these western analyses equal loading was verified by Ponceau red staining (not shown).

Phosphorylation and activation of ERK 1/2 by E2 via the MAPK pathway

To assess whether E2 can induce rapid cellular signaling effects, we measured ERK 1/2 phosphorylation. E2 activated ERK 1/2 phosphorylation in HT29 cells within 5 min after exposure to a $10^{-11} \mathrm{M}$ concentration (Fig. 6), and reached maximum at $10 \mathrm{~min}$. Higher concentrations of E2 induced similar ERK 1/2 phosphorylation, but within shorter time periods (data not shown). Therefore, for technical convenience, we used exposure to $10^{-11} \mathrm{M}$ E2 in these experiments. The extent of ERK 1/2 phosphorylation by E2 was comparable to the effect of IGF-I, a potent and well-documented membranal ERK 1/2 activator, except that the effect of IGF-1 was still significant at $15 \mathrm{~min}$ of exposure, whereas the effect of E2 fell off after reaching its peak at $10 \mathrm{~min}$. Similar time-dependent ERK 1/2 phosphorylation was obtained in MCF-7 cells (data not shown).

We then compared the phosphorylation patterns of ERK $1 / 2$ in HT29 and MCF-7 cells following $10 \mathrm{~min}$ exposure to different concentrations of E2 (Fig. 7). In HT29 cells, E2 increased the level of ERK 1/2 phosphorylation at concentrations of $10^{-9} \mathrm{M}$ and $10^{-7} \mathrm{M}$ (Fig. 7A). In MCF-7 cells, activation of ERK $1 / 2$ phosphorylation was readily measurable at all E2 concentrations tested, even at $10^{-11} \mathrm{M}$ (Fig. 7B). The differences could be explained by the different estrogen receptors repertoire expressed in MCF-7 versus HT29 cells. 
A
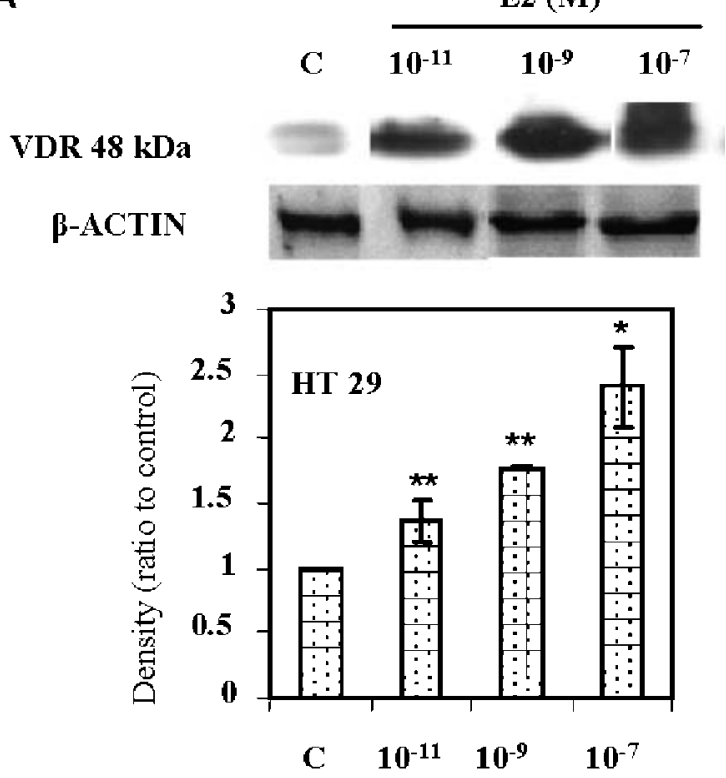

B

VDR 48 kDa

p-ACTIN
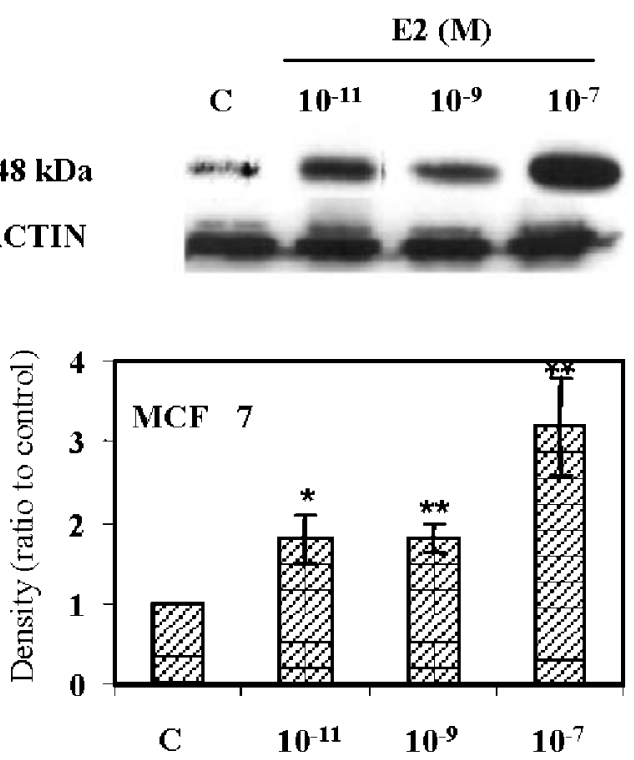

C

HT29

VDR 48 kDa

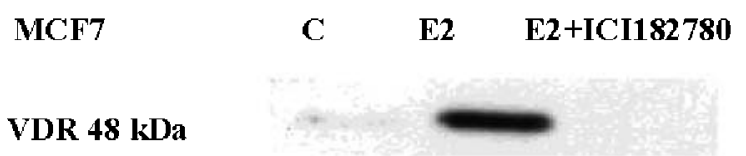

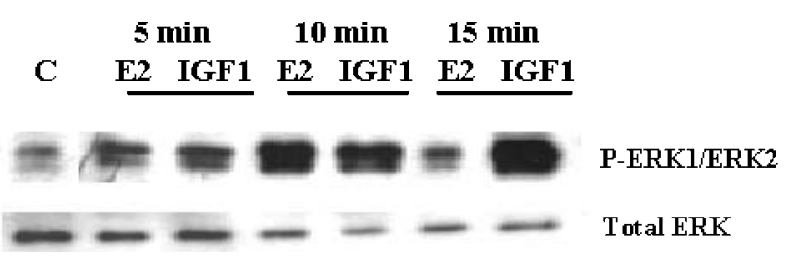

Figure 6 Effect of E2 and IGF-I on ERK 1/2 phosphorylation in HT29 cells. Cells were treated with $10^{-11}$ M E2 or $100 \mathrm{ng} / \mathrm{ml} \mathrm{IGF-I}$ and harvested at the time periods indicated. Total ERK $1 / 2$ was detected with anti-ERK1 and anti-ERK2 antibodies or with anti-phospho-ERK $1 / 2$ antibodies to detect the phosphorylated proteins. Control cells (C) were treated with E2 vehicle (ethanol$0.0067 \% \mathrm{EtOH})$ or with no treatment at all (C). The figure is a representative example of four similar, independent experiments.

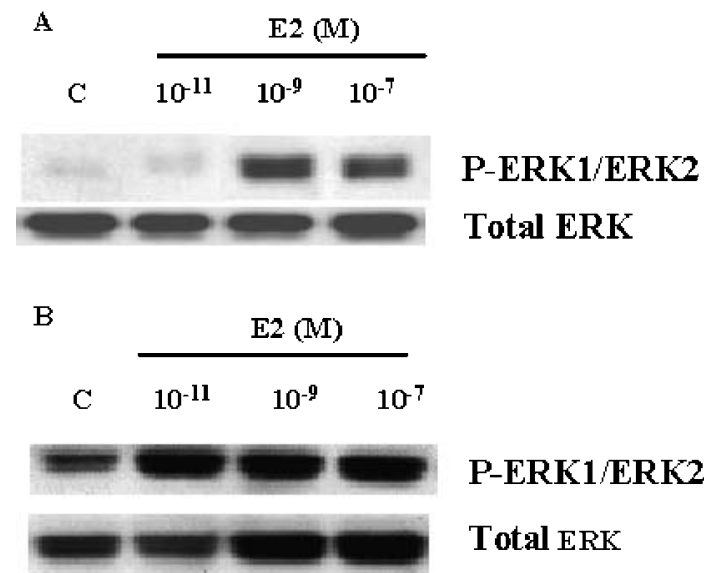

Figure 7 E2-mediated ERK $1 / 2$ phosphorylation in HT29 and MCF-7 cells. ERK $1 / 2$ phosphorylation was measured in HT29 cells (A) and MCF-7 cells (B). The cells were cultured in PR-free DMEM without FCS (HT29) or with 0.5\% FCS (MCF-7) for $24 \mathrm{~h}$ and then treated with different E2 concentrations for $10 \mathrm{~min}$. Control cells (C) were treated with $0.0067 \%$ ethanol. Cell extracts were analyzed as described in the legend to Fig. 6. One representative experiment of three similar ones is shown.

\section{E2 regulates VDR expression via phosphorylation of ERK $1 / 2$}

To determine whether a direct relationship exists between ERK 1/2 activation and VDR expression in HT29 and MCF-7 cells, we used the specific ERK 1/2 phosphorylation inhibitor PD98059 at the previously determined most effective dose $\left(5 \times 10^{-5} \mathrm{M}\right)$. ERK $1 / 2$ phosphorylation and VDR protein expression were evaluated on western blots. We exposed the cells to different E2

Figure 5 VDR protein expression. HT29 (A) and MCF-7 (B) cells were treated with different E2 concentrations for 6 days. Medium and treatment were replaced every other day. Cell extracts were analyzed by SDS-PAGE and immunoblotting using anti-VDR antibody. One representative experiment from three identical ones is shown. Densitometric analyses of VDR western blots for both cell lines are expressed in arbitrary units relative to each cell line control treated with $0 \cdot 0067 \% \mathrm{EtOH}$. (C) Cells treated with $10^{-7} \mathrm{M}$ $\mathrm{E} 2$ in the absence or presence of the ER inhibitor $\mathrm{ICl} 182780$ $\left(10^{-6} \mathrm{M}\right) .{ }^{*} P<0 \cdot 01,{ }^{*} P<<0 \cdot 03$. 


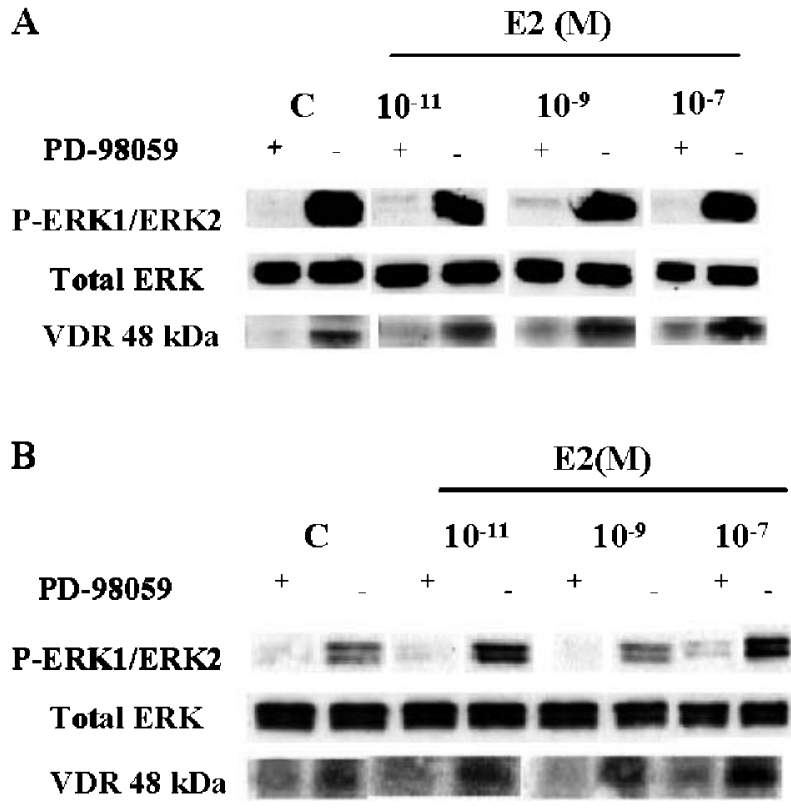

Figure 8 Inhibition of ERK $1 / 2$ phosphorylation and its relation to VDR expression. Effect of PD98059 on ERK 1/2 phosphorylation and VDR expression in HT29 cells (A), and MCF-7 cells (B). Cells were treated with different E2 concentrations and pretreated or not with $5 \times 10^{-5} \mathrm{M}$ PD98059, as described in Materials and Methods. A control treated with $0.0067 \%$ ethanol was used. Cell extracts were analyzed by western blot using an anti-phospho-ERK $1 / 2$ and anti-ERK $1 / 2$ antibodies, or a VDR antibody. One representative experiment of four identical ones is shown.

concentrations and PD98059 for 6 days, the time period previously shown to be required for E2 to induce effective upregulation of VDR expression. In HT29 cells PD98059 completely blocked ERK $1 / 2$ phosphorylation at all E2 concentrations (Fig. 8A), and also prevented the activation of ERK $1 / 2$ in the absence of E2. Basal phosphorylation of ERK $1 / 2$ in the control cells (treated with E2 vehicle, ethanol) was observed in these experiments most likely because cells were exposed to culture media containing FCS. In MCF-7 cells, PD98059 prevented the phosphorylation of ERK 1/2 in the absence of E2 and also blocked phosphorylation at all E2 concentrations (Fig. 8B). In MCF-7 cells, PD98059 abrogated the upregulatory effect exerted by E2 on VDR expression (Fig. 8B). In HT29 cells (Fig. 8A), PD98059 more effectively inhibited the effect exerted by E2 on VDR expression. These differences again, may be due to the different receptor repertoire expressed in these cell lines.

\section{Effect of E2-BSA on VDR expression and ERK $1 / 2$ phosphorylation}

To determine whether E2-induced VDR regulation is mediated by the activity of the hormone at the cell membrane, HT29 cells were treated with an E2-BSA
$\mathbf{A}$

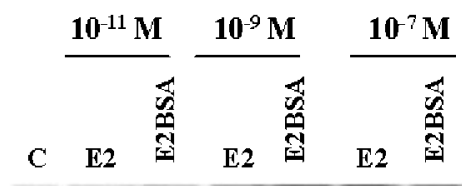

VDR 48 kDa

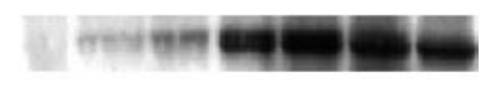

B

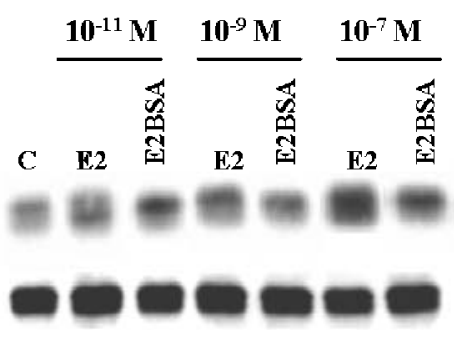

Figure 9 Effect of E2-BSA on ERK 1/2 phosphorylation and VDR expression. (A) HT29 cells were cultured in PR-free DMEM and treated with E2-BSA or E2 for $10 \mathrm{~min}$ at concentrations of $10^{-11} \mathrm{M}$, $10^{-9} \mathrm{M}$, and $10^{-7} \mathrm{M}$. Control cells $(\mathrm{C})$ were exposed to $0.0067 \%$ ethanol. Cell extracts were analyzed by western blot using an anti-phospho-ERK $1 / 2$ and anti-ERK $1 / 2$ antibodies. One representative experiment of three identical ones is shown. (B) HT29 cells were cultured in PR-free DMEM and treated with E2-BSA or E2 for 10 min at concentrations of $10^{-11} \mathrm{M}, 10^{-9} \mathrm{M}$, and $10^{-7} \mathrm{M}$. Control cells (C) were exposed to $0 \cdot 0067 \% \mathrm{EtOH}$. Cell extracts were analyzed by SDS-PAGE and immunoblotting using anti-VDR antibody. One representative experiment of three identical ones is shown.

conjugate that could not traverse the plasma membrane. The effect of E2-BSA mimicked the effect of E2 on VDR protein expression and ERK 1/2 phosphorylation: E2-BSA, at all concentrations tested $\left(10^{-11}-10^{-7} \mathrm{M}\right)$, significantly upregulated VDR expression in HT29 cells (Fig. 9A). Following exposure to E2-BSA for $10 \mathrm{~min}$, significant ERK 1/2 phosphorylation was detected, similar in pattern and intensity to the nonconjugated hormone (Fig. 9B). E2-BSA exerted similar effects on MCF-7 cells (data not shown). We conclude from these experiments that E2 activates MAPK and enhances VDR expression acting at the cellular membrane domain.

Localization of ERa and ER $\beta$ to the plasma membrane and caveolae

Immunoblot analyses detected $\mathrm{ER} \alpha$ protein $(67 \mathrm{kDa})$ and ER $\beta$ protein $(54 \mathrm{kDa})$ in whole-cell lysates of HT29 (Fig. $1 \mathrm{~A})$ and ER $\alpha$ protein $(67 \mathrm{kDa})$ in MCF-7 cells (Fig. 1B). Subfractionation of the cancer cells detected ER $\beta$ in HT29 cells in cytosol, nuclei and plasma membranes (Fig. 10A), and in MCF-7 cells ER $\alpha$ was detected in cytosol, nuclei and plasma membranes (Fig. 10A). ER $\alpha$ and ER $\beta$ were expressed most distinctively in the plasma membrane of HT29 and MCF-7 cells following E2 stimulation (not shown). 
HT29 C $\quad \mathbf{N} \quad \mathbf{M}$

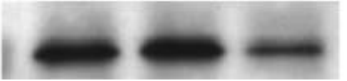

ER $\beta 54$ kDa

MCF-7

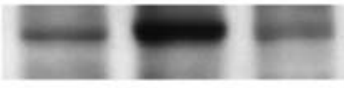

ERo $67 \mathrm{kDa}$

B NCM CAV

HT29

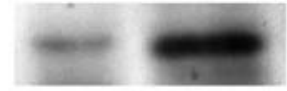

ERP 54 kDa

MCF-7

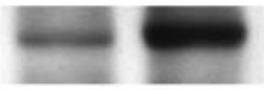

ERo. 67 kDa

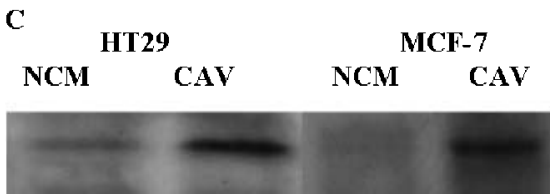

Caveolin-1 21 kDa

Figure 10 Cellular localization of ER $\alpha$ and ER $\beta$ in HT29 and MCF-7 cells. (A) Immunoblot analyses for ER $\alpha$ and ER $\beta$ in MCF-7 and HT29 cancer cells respectively in cytosol $(\mathrm{C})$, nucleus $(\mathrm{N})$ and plasma membrane (M). (B) Localization of ER $\alpha$ and ER $\beta$ to caveolae in E2-treated MCF-7 and HT29 cells. Immunoblot analyses for $E R \alpha, E R \beta$ in noncaveolae membranes (NCM) and caveolae membranes (CAV) obtained from MCF-7 and HT29 cell's whole plasma membranes. Signals were obtained at the expected $54 \mathrm{kDa}$ (for $\mathrm{ER} \beta$ ) and $67 \mathrm{kDa}$ (for $\mathrm{ER} \alpha$ ) in HT29 and MCF-7 cells respectively. (C) Immunoblot analyses for caveolin-1 to confirm caveolae membrane subfractionation. Results are representative of three independent experiments.

Thereafter, additional fractionation experiments were conducted in cells treated with E2. We determined whether ER $\beta$ and $\mathrm{ER} \alpha$ protein $(54$ and $67 \mathrm{kDa}$ respectively) are associated with caveolae subfraction of HT29 and MCF-7 cells' cell plasma membranes. We demonstrate that $\operatorname{ER} \beta$ localizes to the plasmalemmal caveolae in HT29 cells treated with E2 $\left(10^{-7} \mathrm{M}\right)$, (Fig. 10B) and ER $\alpha$ localized to plasmalemmal caveolae in MCF-7 cells treated with E2 $\left(10^{-7} \mathrm{M}\right)$ (Fig. 10B). In contrast, no such association was detected under basal unstimulated conditions (not shown). Immunoblots of caveolae and non-caveolae fractions with anti-caveolin-1 confirmed that the caveolae sub-fractionation technique was satisfactory (Fig. 10C).

Blockade of E2-mediated VDR up-regulation by caveolae disruption

To analyze the function of caveolae in E2-mediated signaling, the cholesterol binding reagent, methylcyclodextrin was used to deplete the cellular cholesterol, which

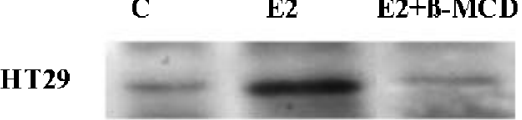

VDR 48 kDa

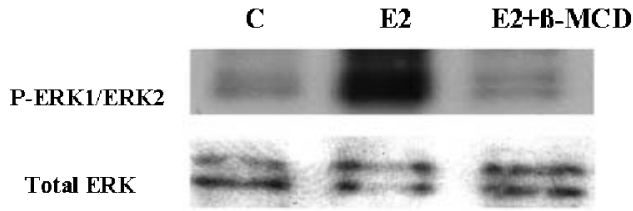

B

MCF-7

C

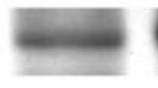

E2

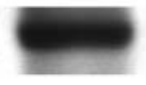

C

E2

P-ERK1/ERK2
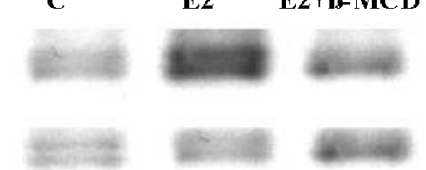

Total ERK

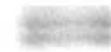

Figure 11 Confirmation of association of ER $\alpha$ and ER $\beta$ in HT29 and MCF-7 cells with lipid rafts/caveolae. HT29 (A) and MCF-7 (B) cells were treated with E2 $\left(10^{-7} \mathrm{M}\right)$, or combined E2 $\left(10^{-7} \mathrm{M}\right)$ and $\beta$-methylcyclodextrin $(\beta-M C D, 10 \mathrm{mM})$ treatment. Cell extracts were analyzed by western blot using VDR and anti-phospho-ERK $1 / 2$ and anti-ERK $1 / 2$ antibodies in HT29 (A) and MCF-7 (B) cells.

is essential for the structural integrity of lipid rafts/ caveolae. We based the experiments on the report by Fielding \& Fielding (2000), and used $10 \mathrm{mM} \beta$ methylcyclodextrin $(\beta-\mathrm{MCD})$ to treat HT29 and MCF-7 cells. After combined E2 $\left(10^{-7} \mathrm{M}\right)$ and $\beta$-MCD $(10 \mathrm{mM})$ treatment, lipid rafts/caveolae were significantly disrupted, as indicated by dislocation of caveolin in density gradient separation (not shown), and inhibition of downstream MAPK signaling and VDR expression in HT29 (Fig. 11A) and MCF-7 (Fig. 11B) cells.

Suramin and PP2 blocks ERK 1/2 phosphorylation induced by E2 and inhibits E2-mediated VDR expression

To investigate the upstream signals mediating E2 action on MAPK, we questioned whether the effects of E2 on MAPK involved Src or other tyrosine kinases. To that end, we used suramin a polysulfonated naphthylurea compound that interferes with the signal exerted by the binding of several polypeptides known as activators of membrane-associated signaling pathways involved in tyrosine phosphorylation. HT29 cells were exposed to different suramin concentrations for $4 \mathrm{~h}$ and then triggered with E2. Assessment of ERK 1/2 phosphorylation indicated that the phosphorylation activity was significantly 
and dose-dependently downregulated in response to suramin. At low suramin concentrations, the inhibitory effect on ERK 1/2 activation was minimal whereas at the $4 \times 10^{-3} \mathrm{M}$ concentration, HT29 ERK $1 / 2$ phosphorylation was completely abolished (Fig. 12A). In parallel experiments cells were treated for 4 days with E2 and then 2 days with both E2 and 1 or $4 \times 10^{-3} \mathrm{M}$ suramin. Suramin dose-dependently inhibited the enhanced VDR expression induced by E2 (Fig. 12B). Similar results were obtained with MCF-7 cells (data not shown). We next used a pan Src inhibitor PP2, which has been recently identified as a potent and selective inhibitor of the Src-family tyrosine kinases, and demonstrated that it blocked E2-induced MAPK phosphorylation, implying that Src family members are required for this step. PP2 in the presence of E2 inhibited dose dependently E2mediated MAPK phosphorylation in HT-29 cells (Fig. 12C). We next wanted to determine whether Src tyrosine phosphorylation is involved in regulating VDR expression mediated by E2. Exactly as for Suramin, PP2 dosedependently inhibited the enhanced VDR expression induced by E2 in HT-29 cells (Fig. 12D). Similar results were obtained with MCF-7 cells (data not shown).

We conclude from these experiments that Src tyrosine phosphorylation of membrane-associated proteins is involved in E2-mediated VDR expression.

\section{Sulindac sulfide inhibits E2-mediated VDR expression}

The ability of sulindac sulfide to inhibit Ras (Herrmann et al. 1998) warrants examination whether sulindac sulfide can inhibit other pathways dependent on Ras. To that end, we incubated HT29 and MCF-7 cells with sulindac sulfide $(100 \mu \mathrm{M})$ in the presence of E2 and tested the effect on VDR expression (Fig. 13). This concentration was chosen following preliminary experiments (not shown). This was accomplished by incubating HT29 and MCF-7 cells in the presence of increasing concentrations of sulindac sulfide and measuring their effect on VDR expression (not shown). Sulindac sulfide at a concentration of $100 \mu \mathrm{M}$ caused the most impressive effect. We therefore chose a concentration of $100 \mu \mathrm{M}$ for all subsequent experiments since this concentration is also consistent with that used in previous studies (Herrmann et al. 1998). We found that sulindac sulfide significantly inhibited E2-mediated VDR upregulation in both HT29 and MCF-7 cells, indicating that Ras signaling is involved in E2-mediated VDR transcriptional control.

\section{Phosphorylation of Raf and c-Jun by E2}

To investigate additional upstream and downstream signals to MAPK mediating E2 action, we questioned whether the effect of E2 involves Raf and c-Jun phosphorylations. Raf and c-Jun were avidly phosphorylated in response to E2 treatment $\left(10^{-7} \mathrm{M}\right)$. Fig. 14 shows that in HT29 cells,
A

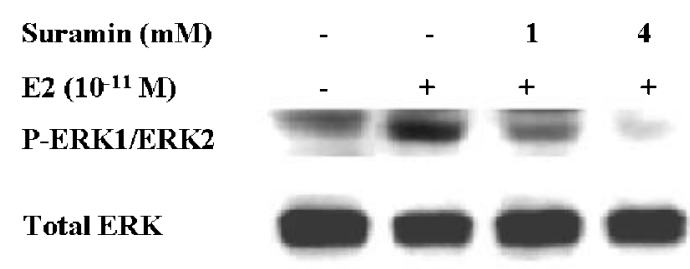

B

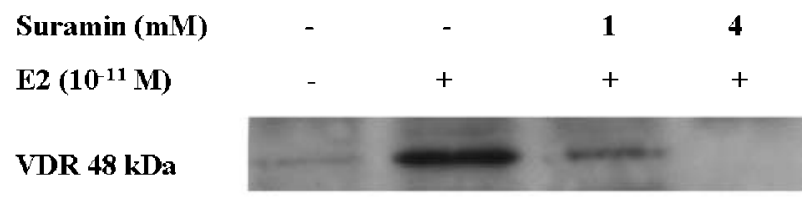

C

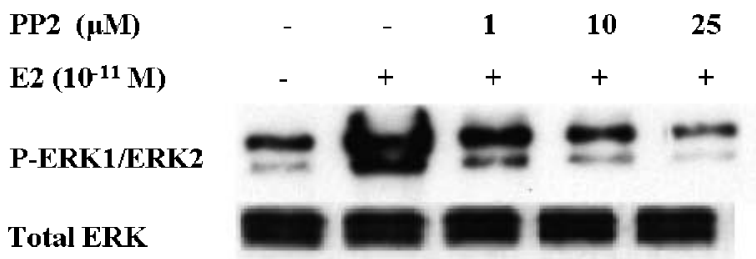

D

$\begin{array}{llllll}\text { PP2 }(\mu M) & - & - & 1 & 10 & 25 \\ \text { E2 }\left(10^{-11} \mathrm{M}\right) & - & + & + & + & + \\ \text { VDR 48 kDa } & & & & & \end{array}$

Figure 12 Effect of suramin and PP2 on ERK 1/2 phosphorylation and VDR expression. (A) HT29 cells were cultured in PR-free DMEM and treated with different suramin concentrations for $4 \mathrm{~h}$ and then exposed to $10^{-11} \mathrm{M}$ E2 for $10 \mathrm{~min}$. Control cells were exposed to $0 \cdot 0067 \%$ ethanol. Cell extracts were analyzed by western blot using an anti-phospho-ERK $1 / 2$ and anti-ERK $1 / 2$ antibodies. One representative experiment of three identical ones is shown. (B) HT29 cells were treated for 4 days with $10^{-11} \mathrm{M} \mathrm{E2}$ and then for 2 days with both $10^{-11} \mathrm{M} \mathrm{E} 2$ and 1 or $4 \times 10^{-3} \mathrm{M}$ suramin. Cell extracts were analyzed by western blot using anti-VDR antibody. (C) Effect of the Src tyrosine kinase inhibitor PP2 on E2-mediated ERK 1/2 activation on HT29 cells. Cells grown in serum-free PR-free medium were treated for $60 \mathrm{~min}$ with vehicle (DMSO) or PP2 (1, 10 and $25 \mu \mathrm{M})$ and then exposed to $10^{-11} \mathrm{M} \mathrm{E2}$ for $10 \mathrm{~min}$. Cell lysates were analyzed by western blot for ERK 1/2 phosphorylation with anti-phospho-ERK 1/2 antibodies. (D) HT29 cells were treated for 5 days with $10^{-11} \mathrm{M}$ E2 and then for 1 day with both $10^{-11} \mathrm{M} \mathrm{E2}$ and PP2 (1, 10 and $25 \mu \mathrm{M})$. Cell extracts were analyzed by western blot using anti-VDR antibody. One representative experiment of three or four identical ones is shown.

Raf was significantly phosphorylated following 5 and $10 \mathrm{~min}$ of exposure to $10^{-7} \mathrm{M} \mathrm{E} 2$, and in MCF-7 cells significant phosphorylation was achieved following at least $10 \mathrm{~min}$ of exposure to $10-^{7} \mathrm{M} \mathrm{E} 2$. c-Jun was significantly 


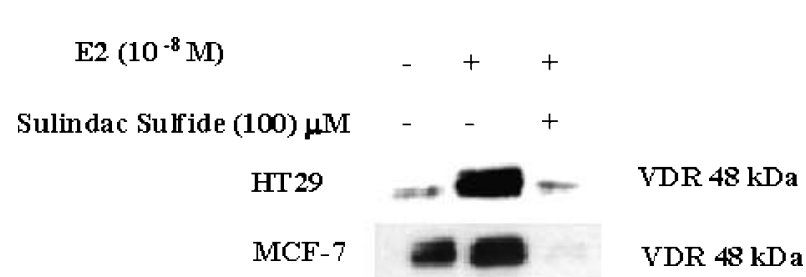

Figure 13 Effect of sulindac sulfide on VDR expression. HT29 and MCF-7 cells were treated with $10^{-8} \mathrm{M}$ E2 or combination of $10^{-8}$ $\mathrm{ME} 2$ and $100 \mu \mathrm{M}$ sulindac sulfide for 6 days. Medium and treatment were replaced every other day. Cell extracts were analyzed by SDS-PAGE and immunoblotting using anti-VDR antibody. One representative experiment from three identical ones is shown.

phosphorylated following 15 min exposure to E2 in HT29 cells, and in MCF-7 cells the phoshorylation process of c-Jun was faster (Fig. 14).

\section{E2 regulates VDR expression via phosphorylation of c-Jun}

To determine whether a direct relationship exists between c-Jun phosphorylation and VDR expression in HT29 and MCF-7 cells, we used the specific c-Jun phosphorylation inhibitor SP600125 at a range of doses previously demonstrated to be non-cytotoxic to the cells. Concentrations higher than $10 \mu \mathrm{M}$ was cytotoxic to both cell lines (data

\section{A HT29}

\section{B MCF-7}

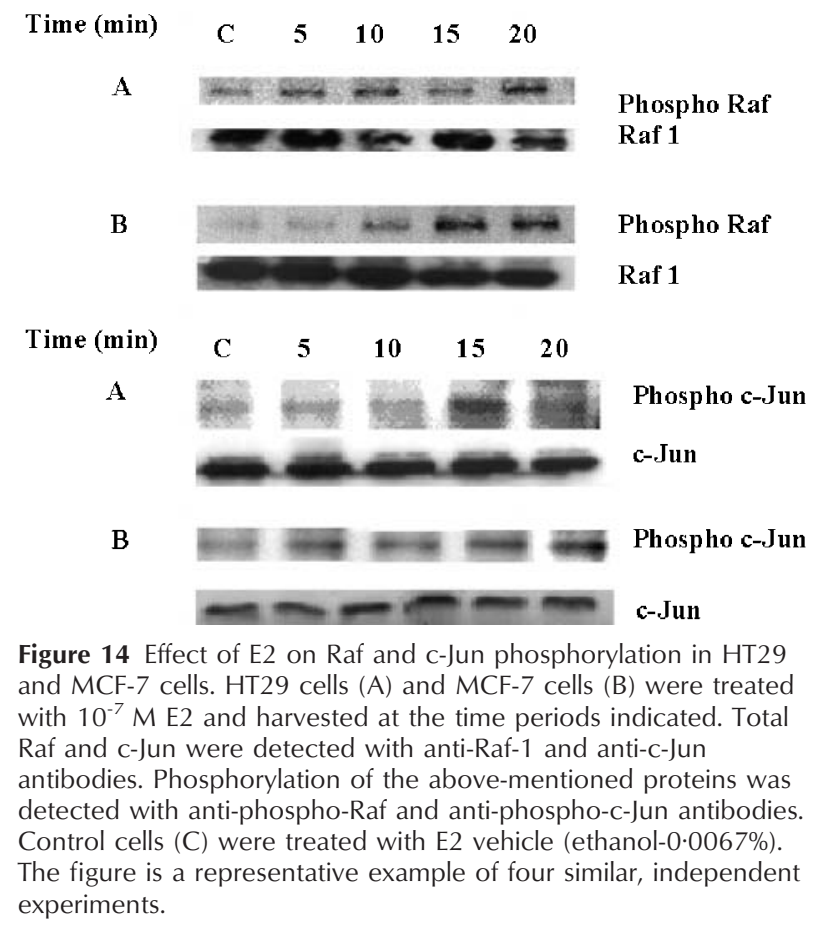

not shown). C-Jun phosphorylation and VDR protein expression were evaluated on western blots. We exposed the cells to E2 $\left(10^{-8} \mathrm{M}\right)$ and various concentrations of SP600125 $(1,2 \cdot 5,5$ and $10 \mu \mathrm{M})$ for 6 days (the exact protocol as for PD 98059), the time period previously shown to be required for E2 to induce effective upregulation of VDR expression. In HT29 cells SP600125 dose dependently inhibited c-Jun phosphorylation and VDR expression (Fig. 15A). Basal phosphorylation of c-Jun in the control cells was observed in these experiments most likely because cells were exposed to culture media containing FCS. Similarly to HT-29 cells, in MCF-7 cells, SP600125 prevented the phosphorylation of c-Jun and concomitantly dose-dependently abrogated the upregulatory effect exerted by E2 on VDR expression (Fig. 15B).

\section{PD98059 blocks c-Jun phosphorylation induced by E2 and inhibits E2-mediated VDR expression}

In order to link MAPK activation with downstream signals we tested the effect of the PD 98059 on c-Jun phosphorylation and concomitantly on VDR expression. E2, as previously described, induced c-Jun phosphorylation concomitantly with VDR enhanced expression in both cell lines (HT-29 and MCF-7; Fig. 16A and B). We exposed the cells to E2 $\left(10^{-8} \mathrm{M}\right)$ concomitantly with $50 \mu \mathrm{M}$ of the MAPK/ERK kinase inhibitor PD 98059. PD 98059 downregulated both c-Jun phosphorylation and VDR expression indicating that upstream and downstream events in this signaling cascade are all related to the control of VDR expression. The MEK1 and MEK2 inhibitor UO 126 at a concentration of $10 \mu \mathrm{M}$ exerted similar effects to those exerted by PD 98059, both on c-Jun phosphorylation and E2-mediated VDR expression (not shown), supporting the view that E2-mediated MAPK activation is linked to c-Jun phosphorylation and VDR expression.

\section{Discussion}

The present report adds to our previous in vivo studies (Liel et al. 1999, Schwartz et al. 2000) by establishing that E2 induces VDR expression in cells originating from several organs. Specifically, we addressed here the question of whether this interaction between E2 and VDR also takes place in vitro in HT29 colon cancer cells and MCF-7 breast cancer cells.

MCF-7 is a breast-cancer-derived cell line representing a typical model of estrogen dependent cell growth and we demonstrate in this study that E2 upregulates MCF-7 proliferation (Tada et al. 1986). Conversely, in HT29 colon cancer cells, estrogen had no effect on cell proliferation in the $\mathrm{E} 2$ concentration range used, which represents physiological E2 concentrations. These results are consistent with similar previously reported effects of E2 in other colon cancer cell types (Fiorelli et al. 1999). 


\section{A. HT-29}

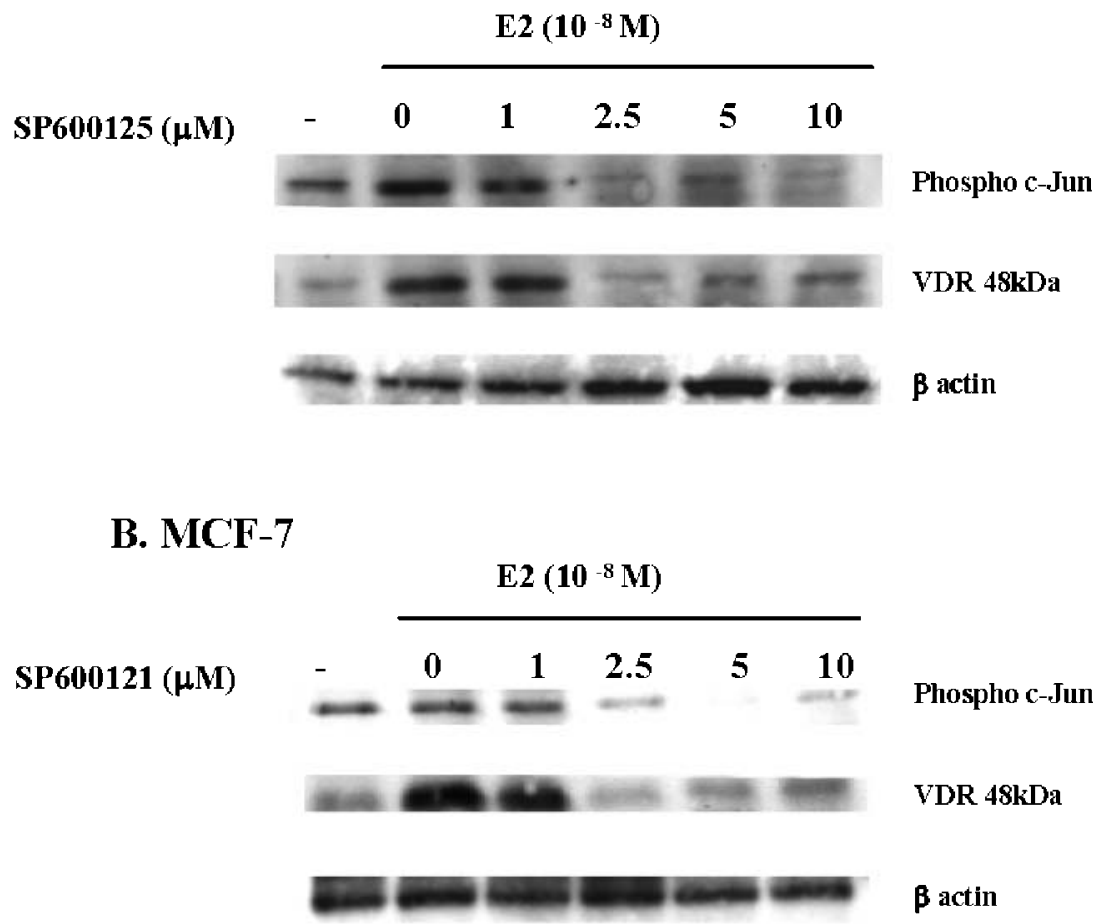

Figure 15 Effect of SP600125 on c-Jun phosphorylation and VDR expression in HT29 cells (A), and MCF-7 cells (B). Cells were treated with E2 $\left(10^{-8} \mathrm{M}\right)$ and with different concentrations of SP600125 $(1-10 \mu \mathrm{M})$, as described in Materials and Methods. Cell extracts were analyzed by western blot using an anti-phospho-jun, or a VDR antibody. One representative experiment of three identical ones is shown.

The reason for the different mitogenic effects exerted by E2 in colon cancer and breast cancer cells may reside in the expression of different estrogen receptors in the two cell lines. In this regard, we demonstrated that HT29 colonocytes express mainly ER $\beta$, supporting previous observations (Arai et al. 2000), whereas MCF-7 cells express mainly ER $\alpha$, as in previously reported findings (Cullen et al. 2000). Further, ER $\alpha$ and ER $\beta$ have different roles in the transcription regulation of various genes. In support of these hypotheses, different responses to AP1activation sites exerted by $\operatorname{ER} \alpha$ and $\operatorname{ER} \beta$ have been described by Paech et al. (1997). Moreover, gene expression of ER $\beta$ in colorectal mucosa has been described (Arai et al. 2000, Campbell-Thompson et al. 2001), but ER $\beta$ is detected at very low levels in breast cancer tissues, according to our and others findings (Cullen et al. 2000). These observations led us to suggest a functional implication for ER $\beta$ in estrogen's mediation of VDR expression in colonic cells. Possible heterodimer or homodimer formation between the different receptors could be responsible for activation of a MAPK signal-transduction pathway (Pettersson et al. 1997).

We demonstrate that E2 affects VDR transcription in both breast and colon cancer cells. We showed that the effect on VDR transcription and protein expression exerted by E2 is mediated by ER, because the ER-specific inhibitor ICI182780 was extremely effective in abrogating E2-mediated VDR upregulation.

E2 may control gene expression by direct nuclear effects following binding to specific DNA sequences. However, no evidence has been accrued demonstrating the existence of estrogen-responsive elements within the VDR promoter. Therefore, we adopted the alternative view that E2 may regulate VDR transcription and expression through signaling pathways. This approach seems feasible because earlier studies have described a TATA-containing promoter immediately upstream of exon $1 c$ of the human VDR gene. This region was shown to be responsive to E2 treatment, resulting in human VDR promoter action in a MCF-7-transfected cell line (Byrne et al. 2000). Therefore, we hypothesized that E2 may stimulate VDR promoter activation by activating a signaling pathway, such as the Raf/MEK (MAPK or ERK kinase)/ERK module of the MAPK cascade since this is a major intracellular mediator of signaling that regulates numerous biological processes.

Treatment with E2 in both HT29 and MCF-7 cell lines significantly induced MAPK activity. Activation of the 


\section{A. HT-29}

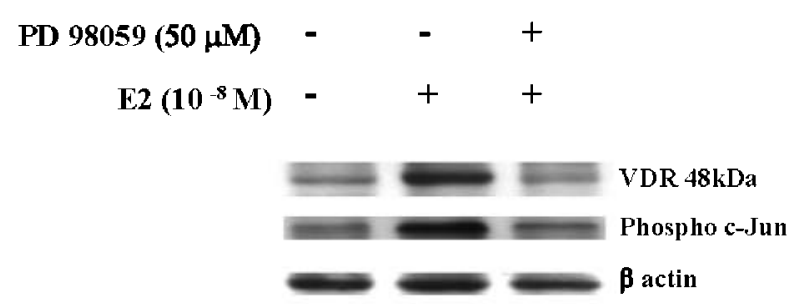

\section{B. MCF-7}

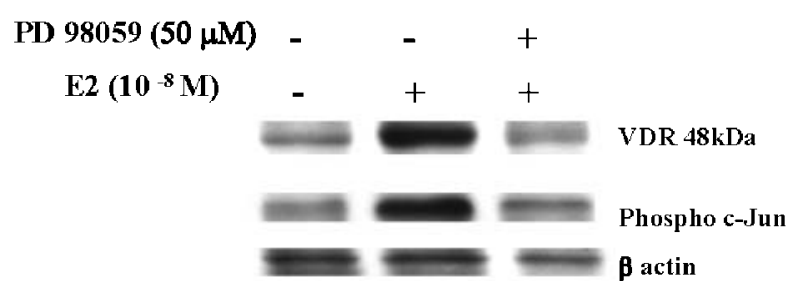

Figure 16 Effect of PD 98059 on c-Jun phosphorylation and VDR expression in HT29 and MCF-7 cells. HT29 cells (A), and MCF-7 cells (B) cells were treated E2 $\left(10^{-8} \mathrm{M}\right)$ and with PD 98059 $(50 \mu \mathrm{M})$, as described in Materials and Methods. Cell extracts were analyzed by western blot using an anti-phospho-jun, or a VDR antibody. One representative experiment of three identical ones is shown.

ERK pathway in MCF-7 cells has already been shown (Migliaccio et al.1996), and a similar effect of MAPK activation in osteoblast-like cells has been previously reported to be exerted by E2 through signaling pathways (Endoh et al. 1997). We showed that ERK $1 / 2$ is activated within short time periods following exposure to E2.

The inhibition of VDR protein expression with the specific ERK 1/2 phosphorylation inhibitor PD98059 in HT29 and MCF-7 cells supports the notion that E2 activation, through ERK 1/2, modulates VDR expression. An interesting observation was that in control cells not exposed to E2 but treated with PD98059, there was complete abrogation of basal MAPK phosphorylation and a concomitant decrease in basal VDR expression (Fig. 8). These results further support the concept that MAPK activation plays a central role in the regulation of VDR expression by E2.

Tyrosine phosphorylation specially src-mediated tyrosine phosphorylation is a well-documented event that occurs following interaction with membrane receptors and signaling. Suramin is a polysulfonated naphthylurea compound that interferes with the signal exerted by the binding of several polypeptides, such as epidermal growth factor (Fujiuchi et al. 1997), IGF1 (Vincent et al. 1996), interleukins (Leland et al. 1995) and tumor necrosis $\alpha$ (LaPushin et al. 1994), which are known activators of membrane-associated signaling pathways involved in tyrosine phosphorylation. In the present study, suramin treatment markedly blocked, in a dose-dependent manner, E2-mediated ERK 1/2 activation in HT29 cells. A similar effect was measured in MCF-7 cells (data not shown). In addition, suramin was shown to inhibit, dose-dependently, VDR expression. Supportive data on the role of src phosphorylation on VDR regulation exerted by E2 was obtained from experiments performed with PP2. Our data show that PP2, a specific Src tyrosine kinase inhibitor, significantly and dose-dependently inhibited ERK activation and subsequently inhibited VDR expression. These findings strongly support the notion that E2 activates intracellular tyrosine signaling induced by src by interacting with putative receptors located at the cellular membrane, and this specific interaction is most probably responsible for the regulation of VDR expression. Flores-Delgado et al. (2001) reported that the nongenomic action of estrogen regulates tyrosine phosphorylation of cytoplasmic proteins in lung myofibroblasts, a finding similar to our observations. Migliaccio et al. (2003) also reported that sex steroids, e.g. estradiol, could act as a growth factor and upregulate signal-transduction pathways.

When HT29 cells were treated with an E2-BSA conjugate, a compound unable to traverse the plasma membrane, the conjugate was able to upregulate both enhanced VDR expression and ERK phosphorylation, in a fashion mimicking almost exactly the effect of the free nonconjugated E2. This finding strongly suggests that the initial signal in ERK 1/2 phosphorylation induced by E2 is generated at the plasma membrane. The effect of the E2-BSA conjugate, together with the suppression of ERK $1 / 2$ activation by suramin and PP2 in HT29 cells and the concomitant inhibition of VDR expression, further suggests that the E2-mediated signal-transduction pathway in colon and breast cancer cells is linked to the activation of putative membrane-receptor-associated tyrosine kinase activity.

Additional upstream events to MAPK phosphorylation reactions (Raf-1 phosphorylation) and downstream to MAPK phosphorylation (c-Jun phosphorylation) demonstrate that E2 induces rapid signaling effects that culminate in phosphorylation of nuclear transcription factors able to induce transcriptional activation of AP-1 sites (Monje et al. 2003). AP-1 sites are present within the VDR receptor and are involved in regulation of VDR transcription (Qi et al. 2002). The specific c-Jun phosphorylation inhibitor SP600125 dose dependently inhibited c-Jun phosphorylation and VDR expression. The MAPK/ERK kinase inhibitor PD 98059 downregulated both c-Jun phosphorylation and VDR expression. These experiments allow us to conclude that upstream and downstream events in the signaling cascade are all interrelated and all participate in the control of VDR expression.

To demonstrate that E2-ER interactions leading to enhanced VDR expression take place at the cell surface we conducted various cellular fractionation analyses to demonstrate the exact localization of ER. ER $\alpha$ and $\beta$ were 

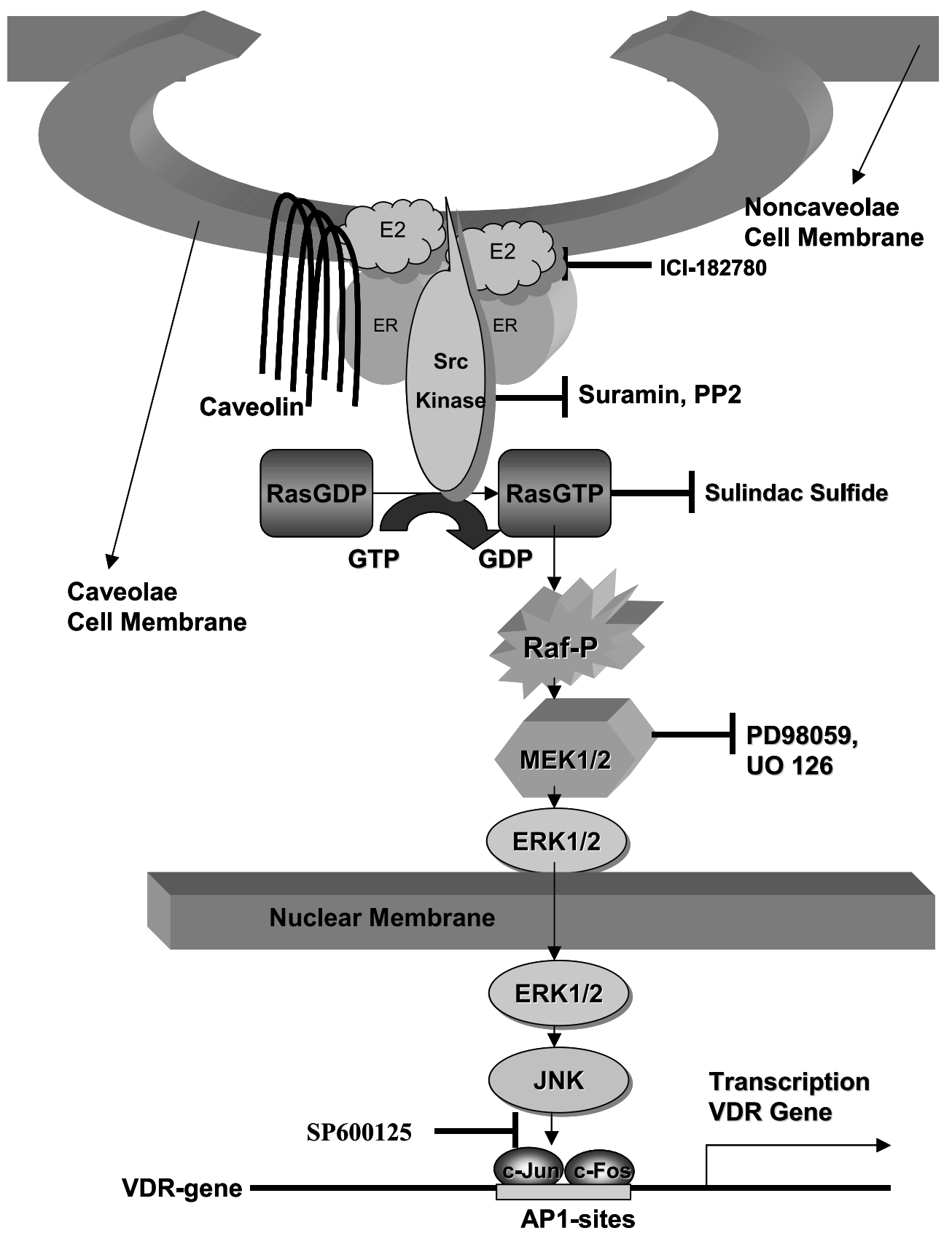

Figure 17 Proposed hypothesis to account for the effect of E2 on ERK 1/2 phosphorylation and concomitant enhanced VDR expression. E2 following binding to caveolae membranal estrogen receptors $E R \alpha$ and ER $\beta$ (in the form of homo- or heterodimers of ER's) induces activation of Src-associated tyrosine phosphorylation, a process that can be inhibited by Src inhibitors such as suramin and PP2. This tyrosine phosphorylation activity triggers the Ras-Raf activation, which can be obliterated by sulindac sulfide. Thereafter MAPK-ERK pathway is activated and as a result c-Jun is phosphorylated inducing it's binding to DNA binding domains such as AP-1 present within the VDR promoter. This interaction finally results in upregulation of transcription and expression of the VDR gene. GDP, guanosine diphosphate, GTP, guanosine triphosphate. 
detected in cellular plasma membrane, cytosol and nucleus of MCF-7 and HT29 cells respectively, revealing identical $\mathrm{ER} \alpha$ and $\mathrm{ER} \beta$ protein species in all cellular compartments. Since signaling molecules are preferentially located in caveolae we also tested whether $\operatorname{ER} \alpha$ and $\beta$ are expressed in caveolae of HT29 and MCF-7 cells. During recent years, more and more reports confirmed that many signaling molecules concentrate in lipid rafts/caveolae, which serve as platforms and play an important role in regulating signal cascades. Signal molecules, such as heterotrimeric G-proteins ( $\mathrm{Li}$ et al. 1995), protein kinase C (Smart et al. 1995), Raf1 (Mineo et al. 1996), and Src family tyrosine kinases (Robbins et al. 1995), are recruited into caveolae by caveolins, which, through the scaffolding domain, interact with the caveolin-binding motifs in these signal molecules (Couet et al. 1997). These clusters of signal molecules can form 'preassembled signaling complexes' on the plasma membrane. Thus, the enrichment of receptors and signal molecules in lipid rafts/caveolae enables them to be in close contact with each other and makes lipid rafts/caveolae the gateways for signals entering into the cells. We clearly demonstrate that in HT29 and MCF-7 cells treated with E2 a significant fraction of ER $\alpha$ and $\operatorname{ER} \beta$ is expressed in caveolae membranes, while in untreated cells the expression is barely discernible. We assume that caveolin may anchor ER proteins to the membrane similarly to that suggested for G-protein $\alpha$ subunit (Couet et al. 1997).

We do not provide information regarding the precise side of the caveolae membrane the estrogen nuclear receptors are localized; knowing that there are at least three possibilities according to Norman et al. (2004). One possibility is that the receptor is located in the outside periphery of the cell but inside the curvature of the caveola interacting with the outer plasma membrane. A second model assumes the existence of an adaptor/scaffold protein that might form a heterodimer with a nuclear receptor to tie it to or near the caveolae. It is known that in Src tyrosine kinase, $\mathrm{G} \alpha$ subunits and $\mathrm{R}$ as each engage in protein-protein interactions with caveolin, the integral membrane protein of caveolae. An additional model proposes that palmitoylation could bind the receptor to the inner surface of the caveola.

The absolute requirement of caveolae membrane localization of ER $\alpha$ and ER $\beta$ in HT29 and MCF-7 cells treated with E2 in the context of signal transduction and VDR expression was further clarified using the cholesterol binding reagent $\beta$-methylcyclodextrin, experiments that demonstrated that inhibition of caveolae membrane localization of ER $\alpha$ and ER $\beta$ directly impinges on VDR expression and MAPK phosphorylation.

Cumulatively our data led us to suggest the hypothesis presented in Fig. 17, namely, that E2 following binding to caveolae membranal estrogen receptors (in the form of homo- or heterodimers of ER's) induces activation of Src-associated tyrosine phosphorylation, a process that can be inhibited by Src inhibitors such as suramin and PP2. Tyrosine phosphorylation activity triggers the Ras-ERK pathway, which ultimately can activate transcription factors such as c-Jun or c-Fos to bind specific sequences within the VDR gene (such as the AP-1 binding site) and finally induce upregulation of transcription and expression of the VDR gene. The authors declare that there is no conflict of interest that would prejudice the impartiality of this scientific work.

\section{References}

Arai H, Miyamoto K \& Taketani Y 1997 A vitamin D receptor gene polymorphism in the translational initiation codon: effect on protein activity and relation to bone mineral density in Japanese women. Journal of Bone and Mineral Research 12 915-921.

Arai N, Strom A, Rafter JJ \& Gustafsson JA 2000 Estrogen receptor $\beta$ mRNA in colon cancer cells: growth effects of estrogen and genistein. Biochemical and Biophysical Research Communications 270 425-431.

Aronica SM, Kraus WL \& Katznellenbogen BS 1994 Estrogen action via cAMP signaling pathway: stimulation of adenylate cyclase and cAMP-regulated gene transcription. PNAS $918517-8521$.

Avioli LV, McDonald JE \& Lee SIN 1965 The influence of age on the intestinal absorption of ${ }^{47} \mathrm{Ca}$ in women and its relation to ${ }^{47} \mathrm{Ca}$ absorption in postmenopausal osteoporosis. Journal of Clinical Investigation 44 1960-1967.

Berthois Y, Pourreau-Schneider N, Gaudilhon P, Mittre H, Tubiana N \& Martin PM 1986 Estradiol membrane binding sites on human breast cancer cell lines. Use of fluorescent estradiol conjugate to demonstrate plasma membrane binding systems. Journal of Steroid Biochemistry 25 963-972.

Blackmore PF, Neulen J, Lattanzio F \& Beebe SJ 1991 Cell surface-binding sites for progesterone mediate calcium uptake in human sperm. Journal of Biological Chemistry 266 18655-18659.

Bullamore JR, Gallagher JC, Wilkinson R, Nordin BEC \& Marshall DH 1970 Effect of age on calcium absorption. Lancet 2 535-537.

Byrne MI, Flanagan L, Tenniswood MPR \& Welsh J 2000 Identification of a hormone- responsive promoter immediately upstream of exon $1 \mathrm{c}$ in the human vitamin $\mathrm{D}$ receptor gene. Endocrinology 141 2829-2836.

Campbell-Thompson M, Lynch IJ \& Bhardwa B 2001 Expression of estrogen receptor (ER) subtypes and ER $\beta$ isoforms in colon cancer. Cancer Research 61 632-640.

Chaban VV, Lakhter JA \& Micevych P 2004 A membrane estrogen receptor mediates intracellular calcium in astrocytes. Endocrinology $1491-23$.

Chang WJ, Ying Y, Rothberg KG, Hooper NM, Turner AJ, Gambliel HA, De Gunzburg J, Mumby SM, Gilman AG \& Anderson RG 1994 Purification and characterization of smooth muscle cell caveolae. Journal of Cell Biology 126 127-138.

Civitelli R, Agnusdei D, Nardi P, Zacchei F, Avioli LV \& Gennari C 1988 Effects of one-year treatment with estrogens on bone mass, intestinal calcium absorption, and 25-hydroxyvitamin D-1 alpha-hydroxylase reserve in postmenopausal osteoporosis. Calcified Tissue International 42 77-86.

Couet J, Li S, Okamoto T, Ikezu T \& Lisanti MP 1997 Identification of peptide and protein ligands for the caveolin-scaffolding domain. Implications for the interaction of caveolin with caveolae-associated proteins. Journal of Biological Chemistry 272 6525-6533.

Csikos T, Chung O \& Unger T 1998 Receptors and their classification: focus on angiotensin II and the AT2 receptor. Journal of Human Hypertension 12 311-318. 
Cullen R, McGuire T, Diggin P, Hill A, McDermott E, O'Higgins N \& Duffy MJ 2000 Detection of estrogen receptor beta mRNA in breast cancer using RT-PCR. International Journal of Biological Markers 15 114-115.

Dokoh S, Donaldson CA \& Haussler MR 1984 Influence of 1,25-dihydroxyvitamin D3 on cultured osteogenic sarcoma cells: correlation with the 1,25-dihydroxyvitamin D3 receptors. Cancer Research 44 2103-2109.

Duncan WE, Glass AR \& Wray HL 1991 Estrogen regulation of the nuclear 1,25-dihydroxyvitamin D3 receptor in rat liver and kidney. Endocrinology 129 2318-2324.

Endoh H, Sasaki H, Maruyama K, Takeyama KI, Waga I, Shimizu T, Kato S \& Kawashima H 1997 Rapid activation of MAP kinase by estrogen in bone cell line. Biochemical and Biophysical Research Communications 235 99-102.

Escaleira MT, Sonohara S \& Brentani MM 1993 Sex steroids induced up-regulation of 1,25- $(\mathrm{OH}) 2$ vitamin D3 receptors in T 47D breast cancer cells. Journal of Steroid Biochemistry and Molecular Biology 45 257-263.

Fielding CJ \& Fielding PE 2000 Cholesterol and caveolae: structural and functional relationships. Biochimica et Biophysica Acta 1529 210-222.

Fiorelli G, Picariello L, Martineti V, Tonelli F \& Brandi LM 1999 Functional estrogen receptor $\beta$ in colon cancer cells. Biochemical and Biophysical Research Communication 261 521-527.

Flores-Delgado G, Bringas P, Buckley S, Anderson KD \& Warburton D 2001 Nongenomic estrogen action in human lung myofibroblasts. Biochemical and Biophysical Research Communications 283 661-667.

Francavilla A, Di Leo A, Polimeno L, Conte D, Barone M, Fanizza G, Chiumarulo C, Rizzo G \& Rubino M 1987 Nuclear and cytosolic estrogen receptors in human colon carcinoma and in surrounding noncancerous colonic tissue. Gastroenterology 93 1301-1306.

Francis RM, Peacock M, Storer JH \& Nordin BEC 1984 Calcium malabsorption in elderly women with vertebral fractures: evidence for resistance to the action of vitamin D on the bowel. Clinical Science 66 103-107.

Fujiuchi S, Ohsaki Y \& Kikuchi K 1997 Suramin inhibits the growth of non-small-cell lung cancer cells that express the epidermal growth factor receptor. Oncology 54 134-140.

Gallagher JC, Riggs BL, Eisman J, Hamstra A, Amoud SB \& Deluca HF 1979 Intestinal calcium absorption and serum vitamin D metabolites in normal subjects and osteoporotic patients. Journal of Clinical Investigation 64 729-736.

Gennari C, Agnusdei D, Nardi P \& Civitelli R 1990 Estrogen preserves a normal intestinal responsiveness to 1,25-dihydroxyvitamin D3 in overectomized women. Journal of Clinical Endocrinology and Metabolism 71 1288-1293.

Glass CK, Rose DW \& Rosenfeld MG 1997 Nuclear receptor coactivators. Current Opinion in Cell Biology 9 222-232.

Gross C, Eccleshall TR, Malloy PJ, Villa ML, Marcus R \& Feldman D 1996 The presence of a polymorphism at the translation initiation site of the vitamin $\mathrm{D}$ receptor gene is associated with low bone mineral density in postmenopausal Mexican-American women. Journal of Bone and Mineral Research 11 1850-1855.

Halachmi S, Marden E, Martin G, MacKay H, Abbondanza C \& Brown M 1994 Estrogen receptor associated proteins: possible mediators of hormone-induced transcription. Science $\mathbf{2 6 4}$ $1455-1458$

Harris SS, Eccleshall TR, Gross C, Dawson-Hughes B \& Feldman D 1997 The vitamin D receptor start codon polymorphism (FokI) and bone mineral density in premenopausal American black and white women. Journal of Bone and Mineral Research 12 1043-1048.

Heaney RP, Recker RR \& Saville PD 1978 Menopausal changes in calcium balance performance. Journal of Laboratory and Clinical Medicine 92 953-963.
Hendrickse CW, Jones CE, Donovan IA, Neoptolemos JP \& Baker PR 1993 Oestrogen and progesterone receptors in colorectal cancer and human colonic cancer cell lines. British Journal of Surgery $\mathbf{8 0}$ 636-640.

Herrmann C, Block C, Geisen C, Haas K, Weber C, Winde G, Moroy T \& Muller O 1998 Sulindac inhibits Ras signaling. Oncogene 17 1769-1776.

Horst RL, Goff JP \& Reinhardt TA 1990 Advancing age results in reduction of intestinal and bone 1,25-dihydroxyvitamin $\mathrm{D}$ receptor. Endocrinology 126 1053-1057.

Jehan F \& DeLuca HF 1997 Cloning and characterization of the mouse vitamin D receptor promoter. PNAS 94 10138-10143.

LaPushin R, Totpal K, Higuchi M \& Aggarwal BB 1994 Suramin inhibits tumor cell cytotoxicity mediated through natural killer cells, lymphokine-activated killer cells, monocytes, and tumor necrosis factor. Journal of Clinical Immunology 14 39-49.

Leland P, Obiri N, Aggarwal BB \& Puri RK 1995 Suramin blocks binding of interleukin-4 to its receptors on human tumor cells and interleukin-4-induced mitogenic response. Oncology Research 7 227-235.

Le Mellay V, Grosse B \& Lieberherr M 1997 Phospholipase C beta and membrane action of calcitriol and estradiol. Journal of Biological Chemistry 272 11902-11907.

Levy J, Zuili I, Yankowitz N \& Shany S 1984 Induction of cytosolic receptors for $1 \alpha, 25$-dihydroxyvitamin D3 in the immature rat uterus by oestradiol. Journal of Endocrinology 100 265-269.

Li S, Okamoto T, Chun M, Sargiacomo M, Casanova JE, Hansen SH, Nishimoto I \& Lisanti MP 1995 Evidence for a Regulated Interaction between Heterotrimeric G Proteins and Caveolin. Journal of Biological Chemistry 270 15693-15701.

Liel Y, Kraus S, Levy J \& Shany S 1992 Evidence that estrogens modulate activity and increase the number of 1,25-dihydroxyvitamin D3 receptors in osteoblast-like cells (ROS 17/2·8). Endocrinology 130 2597-2601.

Liel Y, Shany S, Smirnoff P \& Schwartz B 1999 Estrogen increases 1,25-dihydroxyvitamin receptor expression and bioresponse in the rat duodenal mucosa. Endocrinology 140 280-285.

Luqmani YA, Ryall G, Shousha S, Coombes RC 1992 An immunohistochemical survey of pS2 expression in human epithelial cancers. International Journal of Cancer 50 302-304

Meggouh F, Lointier P \& Saez S 1991 Sex steroid and 1,25-dihydroxyvitamin D3 receptors in human colorectal adenocarcinoma and normal mucosa. Cancer Research 51 1227-1233.

Migliaccio A, Di Domenico M, Castoria G, de Falco A, Bontempo P, Nola E \& Auricchio F 1996 Tyrosine kinase/p21 ${ }^{\text {ras }} /$ MAPK-kinase pathway activation by estradiol-receptor complex in MCF-7 cells. EMBO Journal 15 1292-1300.

Migliaccio A, Castoria G, Di Domenico M, de Falco A, Bilancio A, Lombardi M, Bottero D, Varricchio L, Nanayakkara M, Rotondi A \& Auricchio F 2003 Sex steroid hormones act as growth factors. Journal of Steroid Biochemistry and Molecular Biology 83 31-35

Mineo C, James GL, Smart EJ \& Anderson RG 1996 Localization of epidermal growth factor-stimulated Ras/Raf-1 interaction to caveolae membrane. Journal of Biological Chemistry 271 11930-11935.

Monje P, Marinissen MJ \& Gutkind JS 2003 Phosphorylation of the carboxyl-terminal transactivation domain of c-Fos by extracellular signal-regulated kinase mediates the transcriptional activation of AP-1 and cellular transformation induced by platelet-derived growth factor. Molecular and Cellular Biology 23 7030-7043.

Nahmias C \& Strosberg AD 1995 The angiotensin AT2 receptor: searching for signal-transduction and physiological function. Trends in Pharmacological Sciences 16 223-225.

Nemere I, Dormanen MC, Hammond MW, Okamua WH \& Norman AW 1994 Identification of specific binding pro-branes of chick intestinal epithelium and relationship to transcaltachia. Journal of Biological Chemistry 269 23750-23756. 
Nilsson S, Makela S, Treuter E, Tujague M, Thomsen J, Andersson G, Enmark E, Pettersson K, Warner M \& Gustafsson JA 2001 Mechanisms of estrogen action. Physiological Reviews 81 1535-1565.

Norman AW, Mizwicki MT \& Norman DP 2004 Steroid-hormone rapid actions, membrane receptors and a conformational ensemble model. Nature Reviews. Drug Discovery 3 27-41.

Paech K, Webb P, Kuiper GJ, Nilsson S, Gustafsson JA, Kushner PJ \& Scanlan TS 1997 Differential ligand activtion of estrogen receptors ER $\alpha$ and ER $\beta$ at AP1 sites. Science 277 1508-1510.

Pappas TC, Gametchu B \& Wason CS 1995 Membrane estrogen receptors identified by multiple antibody labeling and impeded ligand binding. FASEB Journal 9 404-410.

Pettersson K, Grandien K, Kuiper GJ \& Gustafsson JA 1997 Mouse estrogen receptor $\beta$ forms estrogen response element binding heterodimers with estrogen receptor $\alpha$. Molecular Endocrinology 11 1486-1496.

Pfahl M 1993 Nuclear receptor/AP1 interaction. Endocrine Reviews 14 651-658.

Pietras R \& Szego CM 1977 Specific binding sites for oestrogen at outer surfaces of isolated endometrial cells. Nature 265 69-72.

Pietras RJ \& Szego CM 1980 Partial purification and characterization of oestrogen receptors in subfractions of hepatocyte plasma membranes. Biochemical Journal 191 743-760.

Qi X, Pramanik R, Wang J, Schultz RM, Maitra RK, Han J, DeLuca HF \& Chen G 2002 Phosphorylation of the carboxyl-terminal transactivation domain of c-Fos by extracellular signal-regulated kinase mediates the transcriptional activation of AP-1 and cellular transformation induced by platelet-derived growth factor. Journal of Biological Chemistry 277 25884-25892.

Robbins SM, Quintrell NA \& Bishop MJ 1995 Myristoylation and differential palmitoylation of the HCK protein-tyrosine kinases govern their attachment to membranes and association with caveolae. Molecular and Cellular Biology 15 3507-3515.

Russell JE, Morimoto S, Brige SJ, Fausto A \& Avioli LV 1986 Effects of age and estrogen on calcium absorption in the rat. Journal of Bone and Mineral Research 1 185-189.

Schwartz B, Smirnoff P, Shany S \& Liel Y 2000 Estrogen controls expression and bioresponse of 1,25-dihydroxyvitamin D receptors in the rat colon. Molecular and Cellular Biochemistry 203 87-93.

Smart EJ, Ying YS, Mineo C \& Anderson RG 1995 A detergent-free method for purifying caveolae membrane from tissue culture cells PNAS 92 10104-10108.
Song KS, Li S, Okamoto T, Quilliam LA, Sargiacomo M \& Lisanti MP 1995 Co-purification and Direct Interaction of Ras with Caveolin, an Integral Membrane Protein of Caveolae Microdomains Detergent-free purification of caveolae membranes. Journal of Biological Chemistry 271 9690-9697.

Tada H, Shiho O, Kuroshima KI, Koyama M \& Tsukamoto K 1986 An improved colorimetric assay for interleukin 2. Journal of Immunological Methods 93 157-167.

Takamoto S, Seino Y, Sacktor B \& Liang CT 1990 Effect of age on 1,25-dihydroxyvitamin D3 receptors in Wistar rats. Biochimica et Biophysica Acta 1034 22-28.

Takeda H, Yamakawa M, Takahashi T, Imai Y \& Ishikawa M 1992 An immunohistochemical study with an estrogen receptor-related protein (ER-D5) in human colorectal cancer. Cancer 69 907-912.

Tesarik J \& Menoza C 1995 Nongenomic effects of 17 beta estradiol on maturing human oocytes: relationship to oocyte developmental potential. Journal of Clinical Endocrinology and Metabolism $\mathbf{8 0}$ 1433-1438.

Theisinger B, Guthke R, Blin N, Welter C \& Seitz G 1993 Influence of steroid hormones on pS2/BCEI gene expression in xenografted colon tumors. In Vivo 7 411-414.

Vincent TS, Hazen-Martin DJ \& Garvin AJ 1996 Inhibition of insulin-like growth factor II autocrine growth of Wilms' tumor by suramin in vitro and in vivo. Cancer Letters 103 49-56.

Walters MR 1981 An estrogen-stimulated 1,25-dihydroxyvitamin D3 receptor in rat uterus. Biochemical and Biophysical Research Communications 103 721-726.

Watters JJ, Campbell JS, Cunningham MJ, Krebs GE \& Dorsa DM 1997 Rapid membrane effects of steroids in neuroblastoma cells: Effects of estrogen on mitogen activated protein kinase signalling cascade and c-fos immediate early gene transcription. Endocrinology 138 4030-4033.

Wehling M 1995 Nongenomic aldosterone affects the cell membrane as a specific target of mineralocorticoid action. Steroids 60 153-156.

Welter C, Theisinger B, Rio MC, Seitz G, Schuder G \& Blin N 1994 Expression pattern of breast-cancer-associated protein pS2/BCEI in colorectal tumors. International Journal of Cancer 56 $52-55$.

Received in final form 1 March 2005 Accepted 2 March 2005 